\title{
Certain Theoretical and Methodological Guidance on the Conceptualization of Psychological Health of Contemporary Students
}

\section{Деякі теоретико-методологічні орієнтири щодо концептуалізації психологічного здоров'я сучасного студентства}

\begin{abstract}
Antonina Kichuk
Ph.D. in Psychology, Assistant Professor

Izmail State University of Humanities, Ukraine 12, Repina str., Izmail, Odessa region, 68600
\end{abstract}

\author{
Антоніна Кічук \\ кандидат психологічних наук, \\ доцент
}

E-mail: tonya82kichuk@gmail.com

orcid.org/0000-0002-2657-661X

Ізлайльський державний гуланітарний університет, м. Ізлаӥл, Украӥна

вул. Репіна, 12, м. Ізмаїл, Одеська обл., 68600

Original manuscript received April 13, 2019 Revised manuscript accepted May 11, 2019

\section{ABSTRACT}

The expanded scientific knowledge about the essence of any psychological phenomenon is a significant background for enhancing of practically-orientated capacity of the process of modern education directing; the latter one being a generally accepted factor of constructive livelihoods of a personality. If the undeniable meaning of psychological health of a personality lies in his success, the role of solution of problematic issues, connected with psychological health, that is an important integrative feature of a personality throughout his life, becomes clear. 
As a result of conducted analytical work it is stated that so far in psychological science there has not been clear understanding of the essence of psychological health, the uniqueness of this attribute, particularly in adolescence. As opposed exactly in this period of life of a person the influence of education on his psychological health is the most notable, as it regards to personal career development during student's life.

It is concluded that in psychological science the outlines of the theory of psychological health of students have already been drawn up in the context of the following idea: "a personality is integral, and an integral individual is personal». Due to the methodological analysis of prediction conducted by the scientists, established inner lines of psychological development of a personality and interpretation of intentional sphere through recognition of the necessity by "energetic carrier» (S. Maksymenko), justification of core aspects of integral-personal approach ( $N$. Nepoleniashcha), proving that any psychological phenomenon is possible to be reflected from different points of view in the context of typological approach, that provides "growth of theoretical knowledge" (T. Dancheva) - the basis for establishing the theory of psychological health of a personality was created. In this regard the fundamental value of philosophical-psychological teaching of an act is proved, in the aspect of which the psychology of youth is taken into consideration ( $V$. Romenets).

The background of the constructive development of psychological health of students, received as a result of empirical research, particularly abroad, that aimed to define practically-orientated approaches to the improvement of educational process at high schools, is also taken into consideration.

Key words: psychic health, psychological health, personality, adolescence.

\section{Вступ}

У науковому просторі психологічної науки помітною є актуалізація уваги до різноманітних аспектів проблеми життєдіяльності студентської молоді. Це зумовлено визнанням виняткового значення цього вікового періоду особистості в освоєнні життєвого простору, наповненні його «особистісним смислом» (О. Леонтьєв, 1975), віднайденні та задіянні освітніх ресурсів щодо особистісної життєвої перспективи. Існує думка, що студентство може 3 «повним правом називатися соціальним нервом суспільства». У цьому контексті загострюється проблематика вироблення 
цілісних наукових уявлень про ті властивості особистості в означений віковий період її життєвого шляху, які мають системний характер, віддзеркалюючи ієрархічну взаємодію різнорівневого відображення єдності внутрішнього і зовнішнього у детермінації психічного. До того ж, актуальним сегментом постають саме ті «зміни, що характерні для конкретної вікової когорти, включаючи пов'язані з розвитком тенденцій, спільні для цієї групи людей» (Бех, 2019: 36). Відтак, природний інтерес становлять ті особистісні властивості, що є визначальними для повноцінного функціонування в окреслений віковий період, задіюючи суб'єктне в ній. Такою властивістю визначено психологічне здоров'я особистості (Роменець, 2004: 8; Царькова, 2014: 129; Максименко, 2019).

Фундатори психологічної науки (Л. Виготський, 1983; О. Леонтьєв, 1975; С. Рубінштейн, 1976 та ін.), враховуючи погляди мислителів і філософів давнини, довели принципову важливість наукового осмислення будь-якого психологічного явища як цілісного; саме цілісне наукове уявлення, розуміння і вивчення психологічного здоров'я особистості дає змогу створити як чітке, так і однозначне визначення його психологічної сутності.

Аналіз наукового фонду, який віддзеркалює дослідницькі розвідки щодо осмислення окресленого психологічного явища і тлумачення конструкту «психологічне здоров'я особистості», доводить зростаючий інтерес до його пізнання з огляду на встановлені тенденції (Максименко, 2019: 44). Ідеться про інтенсивне формування, передусім у молоді, квазіцінностей; домінування соціального запиту на екологічно орієнтовний спосіб життя за наявного стрімкого падіння духовності; підвищення ролі здатності особистості приймати відповідальні рішення за змінних умов життедіяльності у кризових соціально-економічних ситуаціях буття. Зазначене фокусується саме на інтегральній властивості особистості, що репрезентує суто психологічний маркер, з одного боку, здоров'я - як ресур- 
су активного довголіття за умов природних змін у довкіллі, а з іншого - особистості як системної соціальної якості сучасної людини з атрибутивними характеристиками активності та спрямованості, свідомості та самосвідомості. Лаконічне тлумачення означеного, зокрема у контексті цілісно-особистісного підходу до вивчення людини, відтворено у такий спосіб: «особистість цілісна, а цілісна людина - особистісна» (Непомняща, 2005: 117).

Вивчення й узагальнення наукової літератури, де безпосередньо або опосередковано віддзеркалено феноменологію здоров'я особистості у психологічній сфері, дає підстави зауважити, що системні дослідження психологічного здоров'я студентської молоді поки є ще поодинокими. У цій площині чи не найбільшою системністю вирізняються наукові пошуки зарубіжних учених, але за параметром саме практико-орієнтовної складової. Так, у ракурсі занепокоєння академічними стресами серед студентства в університеті Путра Малайзія Прес дослідники (Dhanapal, 2018; Ramachandiran, 2018; Pitt, Oprescu, Tapia \& Ciray, 2018) осмислюють феноменологію психологічного здоров' я особистості з метою розробки психологічних програм підтримки студентів, зважаючи на характер впливовості курсу їхнього навчання на рівень академічного стресу. За набутими результатами проведених емпіричних досліджень установлено, що початок і кінець першого навчального семестру є найризикованішими періодами для негативних наслідків щодо психологічного здоров'я; відтак, командам менеджерів університетів пропонуються розроблені варіанти стратегій, спрямовані на системний підхід до практичного розв'язання проблеми переведення наявного стану загострення академічного стресу студентів на помірний рівень.

Ще й досі у психологічній науці не розроблено теоретико-методологічне обгрунтування концепції психологічного здоров'я особистості, що позначилося на наявній розлогій дискусії відносно наукового статусу ключового поняття - 
«психологічне здоров'я» - з-поміж близьких, відсутності загальноприйнятої наукової позиції щодо структурнокомпонентного складу означеної інтегративної властивості особистості у студентському віковому періоді їі освітньо-професійного зростання, домінуванні поодиноких досліджень, спрямованих на вивчення особливостей (у тому числі й емоційного складника) психологічного здоров'я сучасного студентства й характеру залежностей як індивідуально-психологічної специфіки особистості, так і трендових явищ соціуму. Зазначене обумовило необхідність систематизації дослідницьких підходів, що склались у науковій психології, сукупність конструктивних ідей яких сприятиме концептуалізації цілісного психологічного уявлення про сутність психологічного здоров'я, теоретичних основ його структурно-функціональної моделі та програми психологічного супроводу життєдіяльності особистості у студентський віковий період.

Мета статті - висвітлити наукові підходи до осмислення феномену «психологічне здоров'я особистості», аналіз конструктивності яких сприятиме виробленню концепції, спроможної поглибити наукові уявлення про психологічне здоров'я особистості юнацького віку.

\section{Завдання статті}

На основі набутих результатів проведеної аналітичної роботи обгрунтувати змістове наповнення теоретико-методологічного концепту дослідження проблеми психологічного здоров'я особистості, окреслити особливості психологічного здоров' я особистості в юнацькому віці, що є визначальним у досягненні нею рівня суб’єкта життєвого шляху та здатності до самоідентифікації у процесі визначення траєкторії перспективної життєвої активності.

\section{Методи та методики дослідження}

Репрезентовано системою теоретико-методологічних процедур отримання даних, яка включала: аналіз, синтез 
та узагальнення науково-теоретичних джерел задля окреслення проблемного поля психологічного здоров'я особистості в онтогенезі; порівняння, абстрагування й інтерпретацію наукових даних, що надало змогу визначити базові концепти дослідження.

\section{Результати та дискусії}

Iз метою досягнення об’єктивності психологічного знання про феноменологію психологічного здоров'я особистості, доцільним є звернення до методологічних засад наукової психології - орієнтира у набутті науково виважених результатів. Особливо якщо визнавати, що ще й досі змістовне наповнення поняття «психологічне здоров'я» та його науковий статус складають предмет дискусії серед дослідників.

Установлено, що термін «психологічне здоров' я» введений наприкінці XX ст., тобто значно пізніше, ніж науковці дійшли згоди щодо змісту поняття «психічне здоров'я», його наближеності до стану психічної рівноваги особистості й навіть до тотожності поняттю «душевне здоров'я». Існує й точка зору про доречність розрізняти психічне і психологічне здоров'я людини залежно від причетності або до сфери медицини, або психології (Гаценко, 2004: 33).

У результаті здійсненої, наприклад, В. Войтенком (Войтенко, 1991: 74-75) аналітичної роботи зроблено такі узагальнення: у психічно здорової людини проявляється більш високий рівень здоров'я у психологічній сфері; психологічне здоров'я виступає як динамічна сукупність тих психологічних властивостей, що забезпечують гармонію, з одного боку, між складниками самої особистості та між нею і соціумом, а 3 іншого - створюють можливість повноцінного функціонування впродовж жћитт. Схожою є дослідницька позиція, за якою для опису психологічного здоров' я варто не просто спиратися на поняття «гармонія» як статичний стан, а доречніше виходити з розуміння певного балансу як процесу (Царькова, 2014: 129). Дослідни- 
ця має рацію, наполягаючи ще й на такому зауваженні: послуговуючись терміном «психологічне здоров'я», ми тим самим підкреслюємо неподільність тілесного і психічного в людині та «необхідність і того, й іншого для її повноцінного функціонування» .

Аналіз наукового фонду з проблематики здоров'я особистості у психологічній сфері засвідчує й про таке: численні дослідження віддзеркалюють позиції, за яких дослідники послуговуються одночасно поняттями «психічне здоров'я» $\mathrm{i}$ «психологічне здоров'я», трактуючи їх наближено або як тотожні. Така точка зору обумовлена існуючою розмитістю між психічним станом, психічним процесом, рисами характеру та властивостями особистості. До того ж, як зауважує А. Прохоров (Прохоров, 2000), якщо мати на увазі психічний стан як системне утворення, то його характеризують і багаторівневість, і багатокомпонентність, i поліфункціональність вияву, що в умовах реальної цілісної психічної діяльності через широкий діапазон віддзеркалення «приховує» відмінності між різними станами.

У контексті вищезазначеного нам видається цікавою ідея Т. Данчевої (Данчева, 2012: 50-51) про доречність (з огляду на ієрархізовані психічні властивості та процеси) виокремлювати типи психологічного здоров' я особистості у розрізі ментального, суб'єктного й індивідуального рівнів. А саме: на ментальному рівні системоутворюючим $\epsilon$ сенс розглядати самоактуалізацію (як компонент психологічного здоров'я); на суб’єктному - життєстійкість; на індивідуальному рівні йдеться про адаптивність як компонент психологічного здоров'я. Отож, уможливлюється й типологія окресленої інтегративної властивості особистості: 1) психологічно здорова; 2) психологічно нездорова; 3) самоактуалізуюча особистість; 4) адаптивна; 5) тип життєстійкості особистості.

Попри наявні наукові дискусії, вочевидь бракує обIрунтованих теоретико-методологічних орієнтирів, спроможних визначити науково вмотивований вектор дослід- 
ницького пошуку, що має на меті визначення статусу поняття «психологічне здоров'я», де контекстним виступає саме цілісний погляд на особистість. Адже ж, з одного боку, психологічне здоров’я людини відноситься до «найбільш гострих і актуальних для сучасної світової психології»; важливо розглядати цей феномен як «змістове відгалуження особистості» (Максименко, 2019: 48-50). 3 іншого боку - ідея цілісного погляду на особистість детермінована розумінням своєрідності суб'єкта в психології: психіка розглядається «не як щось, що «висить» у повітрі», а дотично суб’єкта (Непомняща, 2005: 118). До того ж, за О. Брушлинським (Брушлинський, 1994), людина як суб’єкт є вищою системною цілісністю насамперед психічних процесів, станів, властивостей та її свідомого і несвідомого.

У контексті вищезазначеного актуальною є, здебільшого, єдина позиція науковців (Бодальов, 1988; Виготський, 1983; Непомняща, 2005; Рубінштейн, 1976) у розумінні «психіки особистісною» та визнанні конструктивною гуманістичної психології (на противагу природничо-науковій). Погляди вчених на природу пізнання й активність психіки деталізовано М. Ярошевським (Петровський \& Ярошевський, 1999: 184-185): «Прийняте нами трактування категоріальної структури психологічного знання спонукає зарахувати поняття про установку до категорії дії (підкреслюємо ще раз, що дія не повинна бути ототожнена з реакцією...). Субстратом, автором дії, згідно з Д. Узнадзе, є цілісний суб’єкт. Дія - це не реакція організму, а акція особистості. Відповідно, категорія дії першопочатково пов'язана з категорією особистості». Отже, на перший план виведено такі домінанти, як самоактуалізація та самореалізація особистості (Маслоу, 1997), сенс їі буття (Франкл, 1990). А це додає нових якісних ознак самоцінності психологічного здоров'я особистості.

Науковці, предметом дослідницької уваги яких виступає психологічна спадщина 3. Фрейда (Фрейд, 1989), стверджують, що витоки наукового трактування поняття 
«психологічне здоров'я» пов'язані саме з напрацюваннями «видатного дослідника психічного життя людини». Це ілюструє твердження вченого, що здорову людину можуть турбувати внутрішньоконфліктні наслідки, адже ж ідеться про суб'єктну сторону конфлікту. До того ж вважається, що з виходом у світ праці А. Фрейд «Психологія Я і захисні механізми» утверджується ідея про психологічний захист особистості, спрямований на зменшення тривожності через реакції «блокування» та «відвернення в сторону». Таке розуміння прийнято й сучасними дослідниками. Наприклад, уважається (Гаценко, 2004), що психологічний захист виконує й позитивні, й негативні функції, оскільки «неусвідомлено охороняє» особистість від емоційно-негативного перевантаження; усі ж захисні механізми, діючи на неусвідомленому рівні, виступають засобом самообману, «викривляють, заперечують, трансформують, фальсифікують реальність задля того, щоб зменшити тривожність індивіда» .

Суттєво збагачують сучасні уявлення про психологічні механізми захисту особистості й інші дослідники. Попри те, що ці механізми й називають по-різному ( реакція свідомості на психічну травму» за Ф. Бассином, «природне протистояння людини оточуючому середовищу» за О. Гаценко та ін.), все ж домінує серед дослідників спільна позиція відносно того, що йдеться про один із механізмів, який гальмує особистісні зміни.

Нами розумілося, що вихідними положеннями наукової теорії $є$ наукові передбачення, а для вибудовування внутрішньо несуперечливої системи знань про певну психологічну реальність однаково важливі й теоретичні, й емпіричні узагальнення. 3 огляду на предмет дослідницької уваги, вважаємо цінним максимальний масив добутої інформації щодо феноменології психологічного здоров'я особистості. Зокрема, навіть інформації уточнюючого змісту (ідеться про об'єкт чи процес; яким є структурнокомпонентний склад окресленого психологічного явища; 
що є характерним для зв’язків, відносин, залежностей із тими явищами, які постають як родові й видові по відношенню до психологічного здоров' я особистості, тощо). Так, можна припустити, що існуюче нині серед дослідників максимально наближене використання понять «психічне здоров' я» i «психологічне здоров'я» (Войтенко, 2012; Карпенко, 2012; Мединська, 2012; Миколайчук, 2012) обумовлено співіснуванням біологічного і соціального в людині. У цьому зв' язку принципово важливими видаються такі міркування С. Максименка (Максименко, 2019): суто біологічних потреб у людини немає і не може бути; початковою інтенціональною силою $\epsilon$ «потреба як енергетичний носій»; прагнення жити й існувати є біосоціальним, оскільки йдеться про прагнення людини - біосоціальної істоти, що й передано їй соціальними істотами (а не біологічними); «вся еволюція живого на планеті спрямована у бік ускладнення і розвитку нервової системи»; інтенціональна сфера ( «прагнення», «намір») викликає розвиток, існуючий у людині завжди. Науковець, трактуючи інтенцію у контексті змінності форми представлення і особистості, й біологічного, й свідомого, й несвідомого, полемізує не лише із З. Фрейдом (Фрейд, 1989) - стосовно того, що початковим, «інтенціональним елементом людини є чисто біологічні потреби», а й з А. Маслоу (Маслоу, 1997) - відносно значущості поєднання біологічного і соціального у набутті людиною нових інтенцій, Г. Олпортом (Олпорт, 1982) - стосовно витоків «інтенціональної сили» - потреби як енергетичного носія, Л. Виготським (Виготський, 1983) - щодо вибудовування інтенціональної сфрери та її існування у людини «завжди», викликаючи їі розвиток. Відтак, С. Максименко (Максименко, 2019: 11) доходить методологічно вартісного узагальнення: «питання про виникнення свідомості не повинно ставитися в коректному психологічному дослідженні» .

На основі аналізу довідкових джерел щодо трактування поняття «властивість» важливою вважаємо й заувагу, по-перше, відносно розуміння цього поняття як характе- 
ристики (ознаки) певного психологічного явища (у нашому ракурсі - психологічне здоров'я особистості). А, подруге, стосовно встановленої (Виготський, 1983) розбіжності між формально-динамічними (тобто ознаками, що не мають безпосереднього зв'язку зі специфічним соціально значущим змістом ситуації, визначаючи при цьому «енергійність» психологічної діяльності) та змістовими психічними властивостями.

Отож, узагальнюючи сучасні наукові уявлення, що склалися у дослідників за певними вимірами такого психологічного явища, яким постає психологічне здоров'я особистості, та спираючись на довідкові джерела, видається за можливе припустити доречність осмислювати психологічне здоров'я як інтегративну властивість особистості.

Підкреслимо, що наша дослідницька увага сфокусована на особливостях психологічного здоров'я особистості саме юнацького віку. В цій площині неабияке зацікавлення становить фундаментальне дослідження О. Гриньової (Гриньова, 2018), присвячене психології проектування життєвого шляху особистістю у пізній юності з урахуванням просторово-часового і ціннісно-смислового континууму. Спираючись на екзистенційно-суб'єктний підхід і відповідні принципи (смисложиттєвої мотивації студентством образу майбутнього; інтеграції життєвих ліній в особистісному й соціальних світах; смислового переживання особистісної свободи й відповідальності у процесі трансформації життєвих рішень у готовність до реалізації життєвого проекту), вчена, в результаті проведеного комплексного дослідження, доходить висновку, що процес життєдіяльності більшості студентства детермінований не лише альтруїстичними, а й «соціально стереотипними смисловими когніціями й егоцентричними смисложиттєвими орієнтаціями» . Означене набуває суттєвого значення у розширенні наукового знання про особливості психологічного здоров'я особистості саме юнацького віку. Отже, навіть представлений огляд установлених психологічних фактів дає підстави припус- 
тити, що вже наявний теоретичний фонд задля створення теорії психологічного здоров' я особистості.

Так, з огляду на сучасне наукове уявлення про психологічне здоров'я особистості молодої людини, особистісно-професійне зростання якої відбувається в умовах освітнього середовища вищої школи, припускаємо можливість окреслення деяких абрисів вибудовування академічною наукою теорії психологічного здоров'я. У цьому ракурсі природний інтерес становить пророблений С. Максименком (Максименко, 2019) методологічний аналіз процесу прогнозування та встановлені внутрішні лінї розвитку психічного здоров'я особистості. Учений стверджує про важливість урахування при цьому психологічної теорії онтогенезу, аргументуючи свою позицію тим, що еволюція усього живого не є випадковою, а направленою, де форми співіснування біологічного і соціального існують завжди, починаючи із зародження живої істоти, хоча і ці форми зв'язку впродовж життя людини змінюються. До того ж, ученим (у логіці міркувань щодо основ особистості та базових аспектів цілісно-особистісного підходу) по- новому оцінюються, з одного боку, думка Антонія Сурожського про те, що «людина не може бути сама собою, якщо вона не переросте саму себе», з іншого - ідеї П. Флоренського про «потенційну універсальність» і Б. Братуся про «потенційну нескінченність» (Непомняща, 2005). Ідеться, по-перше, про рівневий аспект (адже ж «вищі, духовні, особистісні рівні людини створюють фундамент їі цілісності»); конструктивний аспект (тобто, осмислення людини з точки зору того, якою вона може бути); напівпрожективний аспект (який вимагає від дослідника інтуїції); універсальний аспект, пов' язаний із тим, що базові основи особистості та їх системи визначають різновид психологічних властивостей, якості особистості, особливості різних сфер функціо-

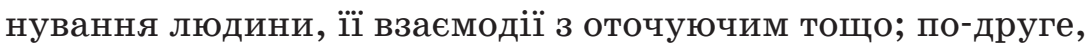
про те, що означене підгрунтя характеризується стійкими рисами - детермінантами індивідуально-типологічної сво- 
єрідності особистості на різних етапах життєвого шляху. Відтак, домінантами цілісно-особистісного підходу визнано такі: 1) «ключем» до розуміння психологічних механізмів є проекція зовнішнього взаємозв’язку на внутрішню цілісність (особистісний аспект); 2) визначальною властивістю є здатність «бути собою й Іншим», природа якої лежить у площині переходу від ігрової діяльності в дитинстві до творчої форми життєдіяльності впродовж життя, тобто репрезентовано суб'єктний аспект.

Принагідно слід підкреслити, що в контексті філософсько-психологічної теорії В. Роменця (Роменець, 2004: 8) суб'єктне (дійове суб'єктивне) постає «у своїй найрозвинутішій формі як внутрішній вчинок». Водночас останнє виявляє себе у формі «зовнішнього вчинку» й творить, формує і розвиває себе найпродуктивніше саме через вчинки. Отже, психологічне знання про вчинок значно розширює межі наукових уявлень про життєтворчість людини впродовж життя, важливим маркером якої виступає її психологічне здоров'я.

Значним пояснювальним значенням характеризується й саме трактування С. Максименком (Максименко, 2019: 8-10) інтенціальної сфери, котру вчений розуміє як «деяку тягу», що існує «відразу» $\mathrm{i}$ «завжди», «викликає розвиток», натомість «ніколи не опредмечується вся». До того ж, учений стверджує, що початковою інтенціальною силою виступає потреба «як енергетичний носій». Аргументуючи свою наукову позицію, він спирається на культурно-історичну концепцію розвитку вищих психічних функцій Л. Виготського, стверджуючи про таке: «потреба завжди має ... зіткнення із соціальною системою, знаковою системою, коли відбувається фактично подвоєння психічного світу особистості».

Відтак, інтерпретуючи вищеокреслене та спираючись на довідкові джерела щодо тлумачення феномену «психологічне здоров'я», уможливлюється констатація наявності складного співвідношення психічного, фізіологічного i 
психологічного у здоров’̈і людини. Ідеться про стан, який забезпечує необхідну їі активність у взаємодії з навколишнім; психічні явища виникають у якості функцій мозку, що, в свою чергу, забезпечує якісне новоутворення, яке проявляється винятково у діяльності людини; психічне здоров'я у змістовому плані віддзеркалює й медичні, й психологічні критерії, охоплюючи i ті соціальні норми,

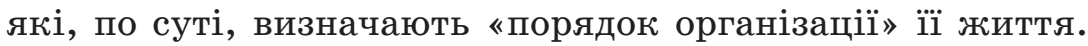
Джерелом активності, рушійних сил, розвитку є інтенції, мотиваційно-потребова сфера особистості; отож, інтенції виступають складником її внутрішнього світу (Максименко, 2019: 7).

До вищезазначених абрисів внутрішньо несуперечливої системи знань про психологічне здоров'я особистості саме в юнацькому віці варто додати конкретизовану в філософсько-психологічній теорії вчинку В. Роменця (Роменець, 2004: 83) психологію юнацтва. Учений зауважує на схильності особистості у цей віковий період до максималістичних умонастроїв і виступів проти буденності, домінуванні ілюзії винятковості, ухиленні від компромісів; особистість юнацького віку характеризують «дух заперечення» $\mathrm{i}$ «дух творчості». Отже, конструктивність окресленого концептуального підходу в контексті наукового знання про психологічне здоров'я можна простежити, зокрема, в ракурсі розуміння вчинку - осередку суб'єктного в особистості, де суб'єктне є уточненням суб'єктивного, а суб’єктивне виступає осередком психічного.

Не менш суттєвою потужністю у зазначеній площині вирізняється й ще один визнаний у науковій психології підхід - типологічний. Головним параметром його конструктивності можна вважати спроможність осмислювати певне психологічне явище з різних точок зору. Так, дбаючи про поглиблення наукових уявлень про психологічне здоров' я особистості в юнацькому віці, видається за можливе забезпечити «приріст теоретичних знань» щодо психологічної сутності досліджуваного феномену. Річ у тому, що змістове 
наповнення типологічного підходу дає змогу забезпечити, як вважають дослідники, вдале узгодження класифікації та опису аналізу і синтезу із систематизацією, а все це $\mathrm{\epsilon}$ підгрунтям установлення найсуттєвіших ознак, зокрема психологічного здоров'я особистості. Оптимальне встановлення релятивної ознаки виступає основою класифікації певного психологічного явища (Данчева, 2012: 50). Отже, йдеться про «економний спосіб пізнання». До того ж, результативність типологічного підходу вбачається ще й у спроможності досягти головного - стійкості перебігу певних ознак того психологічного явища, яке виступає предметом дослідницької уваги.

\section{Висновки}

У результаті проведеної аналітичної роботи уможливлюється вважати, що теоретико-методологічний концепт дослідження проблеми психологічного здоров'я особистості в юнацькому віці лежить у площині: конструктивності цілісно-особистісного підходу; сучасного розуміння домінантою інтенціальної сфери особистості потреби, що виступає в якості своєрідного «енергетичного носія» філософсько-психологічної теорії вчинку, де контентом є психологія юнацтва; ресурсності типологічного підходу в аспекті спроможності як у ракурсі «поглиблення теоретичних знань і їі «економності», так і всебічного осмислення психологічного здоров'я - інтегративної властивості особистості у студентський віковий період їі життєвого шляху.

Подальшими перспективами дослідження є вивчення особливостей емоційного складника психологічного здоров'я особистості у період пізньої юності, котрий значною мірою детермінує її психологічну здатність у подальшому проектувати власний життєвий простір.

\section{Література}

Бех І. Д. Особистість у віковому онтогенезі. Педагогіка і психологія. 2019. № 1. С. 36-43. 
Брушлинский А. В. Проблемы психологии субъекта. Москва : Изд-во Ин-та психологии РАН, 1994. 109 с.

Войтенко В. П. Здоровье здоровых: Введение в санологию. Киев : Здоровье, 1991. $248 \mathrm{c.}$

Выготский Л. С. Проблема возраста: Собр. соч. в 6-ти т. Москва : Педагогика, 1983. Т. 4.332 с.

Гаценко О. Я. Психологическое здоровье и защитные механизмы личности. Наука і освіта. 2004. № 3. С. 33-35.

Гріньова О. М. Психологія проектування особистістю життєвого шляху: юнацький вік. Вінниця : Нілан - ЛТД, 2018. 461 с.

Данчева Т. Д. Типология психологического здоровья личности. Наука $i$ освіта. 2012 . № 3. С. 50-54.

Леонтьев А. Н. Деятельность. Сознание. Личность. Москва : Политиздат, $1975.304 \mathrm{c.}$

Максименко С. Д. Горизонти психологічної науки XXI століття. Педагогіка і психологія. 2019. № 1. С. 44-54.

Максименко С. Д. Джерела активності особистості. Актуальні проблели психологї особистості на Європейськолу просторі: Матеріали IV Міжнар. наук.-практ. конф. (Кам’янець-Подільський, 15 лютого 2019) / Відп. ред. С. Д. Максименко, Л. А. Онуфрієва; Кам’янецьПодільський національний ун-т імені Івана Огієнка. Кам'янецьПодільський : Медобори-2006, 2019. С. 7-11.

Маслоу А. Дальние пределы человеческой психики. Санкт-Петербург : Евроазия, 1997. 430 с.

Непомнящая Н. И. Ценностно-личностный подход к изучению человека. Вопросы психологии. 2005. № 1. С. 116-125.

Олпорт Г. Личность в психологии. Санкт-Петербург : Ювента, 1982. $325 \mathrm{c}$.

Петровский А. В., Ярошевский М. Г. Основы теоретической психологии. Москва : ИНФРА, 1999. 528 с.

Прохоров А. О. Методики диагностики и измерения психических состояний личности. Москва : ПЕРСЭ, 2004. 176 с.

Роменець В. А. Психологія творчості: навч. посіб. Київ : Либідь, 2004. $288 \mathrm{c}$.

Рубинштейн С. Л. Проблемы общей психологии. Москва : Педагогика, 1976. $423 \mathrm{c.}$

Франкл В. Человек в поисках смысла / Под ред. Л. Я. Гозмана, Д. А. Леонтьева. Москва : Прогресс, 1990. 368 с.

Фрейд З. Психология бессознательного: Сб. произв. / Сост., научн. ред., автор вступ. ст. М. Г. Ярошевский. Москва : Просвещение, 1989. $448 \mathrm{c}$.

Царькова О. В. Психологічні аспекти збереження психологічного здоров’ я студентської молоді. Наука і освіта. 2014. № 6. С. 128132. 
Pitt, A., Oprescu, F., Tapia, G., \& Gray, M. (2018). An exploratory Study of Students' weekly Stress Levels and Sources of Stress during the Semester. Active Learning in Higher Education, 19, 1, 61-75.

Ramachandiran, M, \& Dhanapal, S. (2018). Academic Stress among University Students: A Quantitative Study of Generation Y and Z's Perception. Pertanika Journal of Social Science and Humanities, 26, 3, 1115-1128.

\section{References}

Bekh, I. D. (2019). Osobystist u vikovomu ontohenezi [Personality in agerelated ontogenesis]. Pedahohika i psykholohiia - Pedagogy and Psychology, 1, 36-43 [in Ukrainian].

Brushlinskij, A. V. (1994). Problemy psihologii subjekta [Problems on psychology of a subject]. Moskva : Izd-vo In-ta psihologii RAN [in Russian].

Vojtenko, V. P. (1991). Zdorov'e zdorovyh: Vvedenie v sanologiju [Health of Healthy People: An Introduction to Sanology]. Kiev : Zdorov'e [in Russian].

Vygotskij, L. S. (1983). Problema vozrasta [The problem of age]. (Vol. 4). Moskva : Pedagogika [in Russian].

Gatsenko, O. Ja. (2004). Psihologicheskoe zdorov'e i zashchitnye mehanizmy lichnosti [Psychological Health and Protective Mechanisms of Personality]. Nauka i osvita - Science and Education, 3, 33-35 [in Russian].

Hrinova, O. M. (2018). Psykholohiia proektuvannia osobystistiu zhyttievoho shliakhu: yunatskyi vik [Psychology of Designing the Personality's Life Path: Youth Age]. Vinnytsia : Nilan - LTD [in Ukrainian].

Dancheva, T. D. (2012). Tipologija psihologicheskogo zdorov'ja lichnosti [Typology of Psychological Health of the Individual]. Nauka $i$ osvita-Science and Education, 3, 50-54 [in Russian].

Leont'ev, A. N. (1975). Dejatel'nost'. Soznanie. Lichnost' [Activities. Consciousness. Personality]. Moskva : Politizdat [in Russian].

Maksymenko, S. D. (2019). Horyzonty psykholohichnoi nauky XXI stolittia [Horizons of Psychological Science of XXI Century]. Pedahohika i psykholohiia - Pedagogy and Psychology, 1, 44-54 [in Ukrainian].

Maksymenko, S. D. (2019). Dzherela actyvnosti osobystosti [Sources of personality's activity]. S. D. Maksymenko, L. A. Onufriieva (Eds.). Aktualni problemy psykholohii osobystosti na Yevropeiskomu prostori Actual Problems of Psychology of Personality in the European Space: Proceedings of IV International scientific practical conference. (pp. 7-11). Kamianets-Podilskyi : Medobory-2006 [in Ukrainian].

Maslow, A. (1997). Dal'nie predely chelovecheskoj psihiki [The Far Limits of the Human Psyche]. Sankt-Peterburg : Evroazija [in Russian]. 
Nepomnjashchaja, N. I. (2005). Tsennostno-lichnostnyj podhod k izucheniju cheloveka [Value and personality-oriented approach to the study of human]. Voprosy psihologii-Questions on Psychology, 1, 116-125 [in Russian].

Olport, G. (1982). Lichnost v psihologii [Personality in psychology]. SanktPeterburg : Juventa [in Russian].

Petrovskij, A. V., \& Jaroshevskij, M. G. (1999). Osnovy teoreticheskoj psihologii [Fundamentals of theoretical psychology]. Moskva : INFRA [in Russian].

Prohorov, A. O. (2004). Metodiki diagnostiki i izmerenija psihicheskih sostojanij lichnosti [Methods of Diagnosis and Measurement of Mental States of the Individual]. Moskva : PERSJe [in Russian].

Romenets, V. A. (2004). Psykholohiia tvorchosti [The Psychology of Creativity]. Kyiv : Lybid [in Ukrainian].

Rubinshtejn, S. L. (1976). Problemy obshchej psihologii [Problems of general psychology]. Moskva : Pedagogika [in Russian].

Frankl, V. (1990). Chelovek v poiskah smysla [Man in Search of Meaning]. L. Ja. Gozman, D. A. Leont'ev (Eds.). Moskva : Progress [in Russian].

Freud, Z. (1989). Psihologija bessoznatel'nogo [The Psychology of the Unconscious ]. Moskva : Prosveshchenie [in Russian].

Tsarkova, O. V. (2014). Psykholohichni aspekty zberezhennia psykholohichnoho zdorovia studentskoi molodi [Psychological aspects of preservation of psychological health of student youth]. Nauka i osvitaScience and Education, 6, 128-132 [in Ukrainian].

Pitt, A., Oprescu, F., Tapia, G., \& Gray, M. (2018). An exploratory Study of Students' weekly Stress Levels and Sources of Stress during the Semester. Active Learning in Higher Education, 19, 1, 61-75.

Ramachandiran, M, \& Dhanapal, S. (2018). Academic Stress among University Students: A Quantitative Study of Generation Y and Z's Perception. Pertanika Journal of Social Science and Humanities, 26, 3, 1115-1128.

Кічук Антоніна. Деякі теоретико-методологічні орієнтири щодо концептуалізації психологічного здоров'я сучасного студентства

\section{АНОТАЦІЯ}

Розширення наукового знання про сутність будь-якого психологічного явища є суттєвою передумовою посилення практико-орієнтованої потужності процесу спрямування сучасної освіти; остання виступає загальновизнаним дослідниками чинником конструктивної життєдіяльності особистості. Якщо ж виходити з безсумнівного значення психологічного здоров'я особистості в ії успішності упродовж життя, то зрозумілою стає вага своєчасного розв'язання проблемних питань, 
пов'язаних із психологічним здоров'ям - важливої інтегральної властивості особистості упродовж ії життєвого шляху.

У результаті проведеної аналітичної роботи констатовано, що ще й досі у психологічній науці не склалося повне уявлення про сутність психологічного здоров'я, своєрідність цього атрибута особистості, зокрема в юнацькому віці. Натомість саме у цей період життєдіяльності людини найвідчутнішим є вплив освіти на ії психологічне здоров'я, адже ж ідеться про особистісно-професійне зростання в умовах студентського буття.

Установлено, що в психологічній науці вже склалися абриси теорії психологічного здоров'я студентства в контексті такої ідеї: "особистість цілісна, а цілісна людина - особистісна». Завдячуючи проробленому науковцями методологічному аналізу прогнозування та встановленим внутрішнім лініям розвитку психологічного здоров'я особистосmі, трактуванню інтенціальної срери через визнання саме потреби "енергетичним носієм» (С. Максименко), обгрунтуванню базових аспектів цілісно-особистісного підходу (Н. Непомняща), доведенню, що будь-яке психологічне явище видається за можливе осмислювати 3 різних точок зору саме в контексті типологічного підходу, який забезпечує «приріст теоретичних знань» (Т. Данчева) -створено основи для розробки теорії психологічного здоров'я особистості. У цьому зв'язку доведено й фундаментальне значення філософсько-психологічного учіння вчинку, в ракурсі якого враховано психологію юнацтва (В. А. Роменець).

Ураховано й досвід, накопичений унаслідок проведених емпіричних досліджень, зокрема, в зарубіжжі, що спрямовані на визначення практико-орієнтованих підходів до вдосконалення освітнього процесу сучасних вищих шкіл - передумови конструктивного розвитку психологічного здоров'я студентської молоді.

Ключові слова: психічне здоров'я, психологічне здоров'я, особистість, юнацький вік.

Кичук Антонина. Некоторые теоретико-методологические ориентиры концептуализации психологического здоровья современного студенчества

\section{АННОТАЦИЯ}

Расширение научных представлений о сущности любого психологического явления является существенной предпосылкой усиления практико-ориентированных возможностей современного образования; имен- 

но последнее и общепризнано исследователями как фактор успешной жизнедеятельности личности. Если исходить из несомненной ченности психологического здоровья личности в конструктивном определении траектории жизненного пути, то вполне очевидным представляется значение своевременного разрешения проблемных вопросов, связанных с психологическим здоровьем - важнейшей интегративной особенностью личности в процессе всей её жизни. В результате проведенной аналитической работы констатируется, что до сих пор в психологической науке не сложилось единопризнанное и полное представление о психологическом здоровье, специфике этого атрибута личности, в частности, в период её зрелой юности. Между тем, именно в этом возрастном периоде жизнедеятельности человека наиболее весомым является формирующее влияние образования на процесс личностно-профессионального взросления в условиях студенческой среды.

Установлено, что в психологической науке уже сложились очертания теории психологического здоровья студенчества в контексте такой идеи: "личность целостна, а целостный человек - личностный». Благодаря фундаментальности выполненного учеными методологического анализа прогнозирования как прочесса, обоснованию внутренних линий развития психического здоровья личности, трактовке интенциональной сферы через определение именно потребности в качестве "энергетического носителя" (С. Д. Максименко), очерченности базовых аспектов целостно-личностного подхода (Н. И. Непомнящая), установлению фракта, что любое психологическое явление целесообразно изучить с разных точек зрения именно в контексте типологического подхода, который обеспечивает «прирост теоретических знаний» (Т. Данчева) - созданы основы для разработки теории психологического здоровья личности. В этой связи по-новому оченена актуальность и конструктивность философско-психологического учения о действии (поведении), его контекстность для изучения психологии юношеского периода (В. Роменеи).

Учтен и накопленный в результате проведенных исследований (в частности, зарубежными учеными) опыт, направленный на апробацию практико-ориентированных подходов, связанных с совершенствованием образовательного прочесса в учреждениях высшего образования - предпосылки конструктивного развития психологического здоровья студенческой молодежи.

Ключевые слова: психическое здоровье, психологическое здоровье, личность, юношеский возрастной период. 